\title{
Schools Climate and Student Achievement in Secondary Schools of Ethiopia
}

\author{
Abeya Geleta (PhD) \\ Jimma University, College of Education and Behavioural Sciences, \\ Department of Educational Planning \& Management
}

doi: 10.19044/esj.2017.v13n17p239 URL:http://dx.doi.org/10.19044/esj.2017.v13n17p239

\begin{abstract}
A corelational research design was employed to examine if a relationship exists between organizational school climate and student achievement in Ethiopia secondary schools setting, and to investigate whether the various elements of school climate have independent effects on student achievement. Organisational climate was measured using the School Climate Index (SCI) developed by Tschannen-Moran, Parish and Dipaola and student achievement was measured by students' test scores at the Ethiopia General Education Leaving Certificate Examination (GELCE) in the year 2014/15. A total of 32 schools, 973 teachers and 14882 students were involved in the study. Descriptive statistics such as mean and standard deviation, Pearson $r$ correlation coefficient and multiple regression analysis were applied for the data analysis. The results indicate that school climate has a significant and positive relationship with student achievement in Ethiopia secondary schools, but nonetheless, a weak one. The collegial leadership, teacher professionalism, and academic press were significantly and moderately correlated to students' achievement while the community engagement sub scale was not. The four factors used both for the SCI as predictor variables in the regression model were shown to have a significant relationship with student achievement when viewed as a whole, but they generated more varied results when examined individually. Teachers' professionalism is the most positive predictor of student achievement in Ethiopia secondary schools. Similarly collegial leadership and academic press are also found to be significant predictor of academic achievement. This study found no independent effect of community engagement on student achievement. It is recommended that school leaders should design school improvement plans that entail the school climate construct. School leaders need to find ways of including the community in the life of the school and foster positive relationships with the community. Principals in
\end{abstract}


particular need to be mindful that the climate of a school affect achievement and the former can be enhanced to improve results.

Keywords: Ethiopia; school climate; student achievement; collegial leadership; teachers' professionalism; academic press; community engagement

\section{Back ground of the study}

As stakeholders demand for quality education, school leaders often exert efforts into responsive mechanisms that could lead to school improvement and increased student performance. The Ethiopia educational system is no exception to societal pressures for improved student performance; thus, school leaders in Ethiopia often search for ways of meeting the demands of an ever-changing society. Success in national and regional exams remains one of the priorities of the Ethiopia educational system. In the midst of the global movement toward higher quality in education, Ethiopia educators continuously seek best practices to ensure that there is an environment of academic excellence in the classrooms.

Secondary schools in Ethiopia play the crucial role of educating the young people in the country. Students who attend secondary schools first cycle (Grade 9-10) are given the opportunity to sit for national exams known as General School Leaving Certificate Examination (GELCE). These standardized examinations are given yearly to tenth grade high school students and focus on a variety of subjects that the students take while attending secondary school.

As with any educational system, some secondary schools in Ethiopia perform better on these examinations than others. A closer look at this situation quickly reveals that in the secondary schools there are disparities in academic achievement. Differences in academic achievement may exist for varying reasons, one of which is differences in cognitive ability. However, the cognitive ability only accounts for a portion of the disparity in academic achievement. Researchers in the area believe that many factors other than academic abilities affect academic achievement. These factors are often external to the individual and include school and environmental characteristics. Some of these factors include socioeconomic status (Barton, 2004; Klinger, 2000;Willie, 2001), parental involvement (Barnard, 2004; Evans, Shaw \& Bell, 2000; Fan \& Chen, 2001; Okpala, Okpala \& Smith, 2001; Strayhorn, 2010; Wu \& Qi, 2006), principal leadership style (Blase \& Blase, 2000; Goleman, 2006; Hallinger, 2003), teacher and student engagement (Bryson \& Hand, 2007; Cawelti, 2000) and method of instruction (Miller \& Calfee, 2004; Rumberger \& Thomas, 2000). 
A number of factors affect academic achievement, and recently, a growing body of literature has indicated that yet another school factor, school climate, affects student academic achievement. Studies have shown that there is a positive relationship between organizational school climate and student academic achievement (Goddard, Sweetland \& Hoy, 2000; Heck, 2000; Smith, 2002; Uline \& Tschannen-Moran, 2008). The success of a school to accomplish its purposes depends partly on positive school climate. Healthy and smooth working relationships and interactions among and between the principal, the teachers, the students, and other stakeholders profoundly affect student achievements.

According to Perkins (2006), school climate is the learning environment created through the interaction of human relationships, physical setting, and psychological atmosphere. A favourable school climate provides the structure within which students, teachers, administrators, and parents function cooperatively and constructively (Van Houtte, 2005).

The total environment of school consists of its: ecology, social system, milieu and culture (Owens, 1987). School climate defined as the collective personality of a school or a school system. It is the atmosphere that prevails in an organization and is characterized by the social and professional interactions of the people. Owens (1987) has also noted that organizational/school climate is the study of perceptions that individuals have of various aspects of the environment in the organization.

The climate of a school may enhance or constrain the performance of teachers and other staff members of the school. Favourable school climate promotes good relationship between principals and teachers and among school stakeholders which promotes school performance (Hoy and Tarter, 1997). School principals should, thus, actively support and motivate teachers, students and the rest of the staff members to create a favourable working atmosphere within the school. Such an effort of the principal would help to develop an orderly and a productive school climate which improves the students' achievement and overall effectiveness of the schools.

School climate studies provide useful information for school administrators who are interested in building healthy relations in their schools. For these leaders who seek innovative ways of improving their school environment and, thus, the academic success of their students, school climate studies merit some attention. This study, in particular, provides further insights on the topic of school climate as it focuses on the relationship between organizational climate and academic achievement in secondary schools. 


\section{Statement of the Problem}

Despite the fact that various school improvement efforts are currently underway at all levels of schools by the MOE, it is commonly heard from school staff members and the community at large that there is lack of such a conducive and orderly school climate in the Ethiopia secondary schools. Studies revealed that a positive school climate is associated with positive student learning and academic achievement, increased student graduation rates, and teacher retention, decreased student absenteeism in high school (Gottfredson \& Gottfredson, 1989) and with lower rates of student suspension in high school (Lee, Cornell, Gregory \& Fan, 2011).

A positive school climate has a powerful influence on the motivation to learn (Eccles et al., 1993); mitigating the negative impact of the socioeconomic context on academic success, contributing to less aggression and violence (Gregory, et al., 2010); less harassment and acting as a protective factor for the learning and positive life development of young people (Astor, Benbenisty, \& Estrada, 2010).

In addition to these areas, studies also indicate that quality of the school climate is also responsible for academic outcomes as well as the personal development and well-being of pupils (Haahr, Nielsen, Hansen, \& Jakobsen, 2005; OECD, 2009). Thus, school climate is directly related to academic achievement and the effect of positive school climate not only contributes to immediate student achievement, but its affect seems to persist for years (Hoy, Hannum, \& Tschannen-Moran, 1998).

School climate can make differences in the learning environment of schools and in the achievement of students. Thus, it is indispensable that principals and teachers should strive to establish an inviting, orderly and positive school climate of their schools so as to enhance the teachinglearning processes and facilitate the achievement of the schools' objectives. Researchers in the field suggested that studying the climate of schools contributes to understand and improve schools functioning (Hoy and Miskel, 1997).

Early studies on student academic achievement primarily focused on the effects of socioeconomic status. The research literature has shown that this factor is correlated with student achievement and does have some effect on the latter (Barton, 2004; Klinger, 2000; Malecki \& Demaray, 2006; Willie, 2001).

Other studies, however, have provided evidence indicating that socioeconomic status is not the major factor affecting student achievement. Additional external factors have been identified as playing important roles in determining academic success (Barnard, 2004; Oppdenaker \& Damme, 2001; Uline \& Tschannen-Moran, 2008). This study investigates how one such factor organizational school climate - affects student achievement in the Ethiopia 
educational context. It seeks to find out whether school climate facilitates (or hinder) students academic achievement in Ethiopia secondary schools. To this end the following research questions were considered:

1. What is the level of organisational/school climate as perceived by teachers in terms of collegial leadership, teachers' professionalism, community engagement and academic press?

2. What is the relationship between overall organizational climate, as measured by the SCI, and overall student achievement on the $10^{\text {th }}$ Grade national examination (GELCE) in Ethiopia secondary schools?

3. What is the relative weight of each of the factors of school organizational climate in relation to student achievement on the on the $10^{\text {th }}$ Grade national examination?

\section{Purpose of the Study}

The purpose of this study was to determine if a relationship exists between organizational school climate and student achievement in Ethiopia secondary schools, and to explore whether the various factors of school climate have independent effects on student achievement. Organisational climate was measured using the School Climate Index (SCI) developed by Tschannen-Moran, Parish and Dipaola (2006). This instrument looks at four aspects of the organization: collegial leadership, teacher professionalism, academic press, and community engagement. Student achievement was measured using students' test scores at the Ethiopia General Education Leaving Certificate Examination (GELCE) in the year 2014/15.

\section{Conceptual Framework}

Research on organizational climate reveals that there are many ways in which climate is defined and operationalised. Over the years, two main frameworks of school climate emerged. Early works of Halpin and Croft (1963) laid the foundation for the open schools framework while the work of Hoy and his colleagues (Hoy \& Clover, 1986; Hoy \& Forsyth, 1986; Hoy \& Miskel, 1991; Hoy, Tarter \& Kottkamp, 1991) have contributed to the healthy schools framework. These two frameworks have been used to construct various school climate instruments used to measure school climate. Both frameworks focus on the interrelationships between individuals and the interactions that occur between and among individuals in a school.

Over the years, researchers have realized that many of the subscales that exist in both frameworks overlap and can be combined to form consolidated frameworks. The conceptual underpinning of this study lies in a consolidated school climate framework developed by Tschannen-Moran, Parish and Dipaola (2006). These researchers combined elements of the open schools framework (work of Halpin and Croft, 1963) and elements of the 
healthy schools framework (work of Hoy and his colleagues, Hoy \& Clover, 1986; Hoy \& Forsyth, 1986; Hoy \& Miskel, 1991; Hoy, Tarter \& Kottkamp, 1991) to develop a consolidated framework called the School Climate Index (SCI). This framework presented by Tschannen-Moran, Parish and Dipaola (2006) looks at the interactions in a school in terms of collegial leadership, teacher professionalism, academic press, and community engagement. These subscales provide the basis for this current study which focused on the relationship between school climate, as measured by this framework, and student achievement in a school. This framework, and in effect this study, can be very useful to educators because the interactions that occur in a school do affect the operation of a school.

\section{Operationalisation of the Variables in the Conceptual Framework}

Collegial leadership: principal behaviours perceived as supportive and collegial and not overly directive or restrictive (Uline \& TschannenMoran, 2008). Behaviours of such a principal include being friendly, approachable, willing to make changes, sets clear expectations for faculty, and treats all faculty members as his or her equal.

Teacher professionalism: Behaviours that show that teachers are committed to their work and are willing to work cooperatively with one another\| (Tschannen-Moran, Parish \& Dipaola, 2006, p. 397). Such behaviours include respecting the professional competence of their colleagues, accomplishing their jobs with enthusiasm, providing strong social support for their colleagues, and displaying a high level of commitment to helping students.

Academic press: A school-wide tone that is serious, orderly, and focused on academics. Schools with a high level of academic press are driven by a quest for excellence\| (Tschannen-Moran, Parish, \& Dipaola, 2006). In such an environment, the school sets high standards for academic performance and students respect each other who get good grades; academic achievement is recognized and acknowledged by the school, and students seek extra work so that they can get good grades.

Community engagement: This construct describes the degree to which the school can count on involvement and support from parents and community members, and the extent to which the school provides the community with information about its accomplishments (Uline \& Tschannen-Moran, 2008).

Ethiopia General Secondary Education Certificate Examination (ESELCE): Criterion-referenced examination given at the completion of the first cycle of general secondary education and performance on examination determined admission into the second cycle preparatory education or opt for vocational training (MoE, 2010). 
Organizational/school climate: the set of internal characteristics that distinguishes one school from another and influences the behaviour of its members (Hoy \& Hoy, 2009).

\section{Significance of the study}

The increased emphasis on quality education and student achievement is causing many schools to engage in scrutiny to determine how best to improve student performance. This study highlighted one aspect education leaders can examine in their schools if their aim is school improvement. This study provides important information to school leaders and educators as it gives them an additional opportunity to consider when looking at factors that can possibly influence student achievement. This information becomes very helpful in the planning process particularly in school improvement plans. Because this study uses an instrument that focuses on four different aspects of the school organisation, school leaders can consider each of these aspects when developing their school improvement plans. Most school climate studies have been conducted in developed countries. This study, however, is conducted in different setting (Ethiopia) where the structure, dynamics, management, and systems of schools differ from those of the developed ones. Hence, conducting a study in this different setting may add new knowledge to the school climate area.

\section{Research Design and Methodology Research Design}

A non-experimental corelational design was selected for this study. The non-experimental corelational design was selected because of its quantitative nature in examining whether a relationship exists between school climate and student achievement. Correlational research can provide information that allows predictability based on associations. In this study, there was an interest in the variables of school climate and student achievement. Thus, a corelational study was employed to determine if any relationship exists between the two. Correlational research allows for the analysis of multiple variables in one study, and it also indicates the degree of relationship among variables. This is, therefore, a very practical design for this study as various factors of school climate were looked at and the degree of relationship was an area of interest. The current study was to determine if a relationship exists between school climate and student achievement but not to investigate if one was caused by the other. It should be noted that corelational research does not provide for causality. McMillan (2004) stated that the most important principle in evaluating correlation research is not to infer causation. 


\section{Sample Size and Techniques}

The population for the study includes students, teachers and principals of secondary schools in Oromiya Regional state, Ethiopia. Oromia Regional State has eighteen Zonal administrations which are clustered in the location of east, south-east, western and central Oromia zones. West Oromiya cluster, which consists of nine zones, was purposively selected for the study. Out of these nine zones found in Western cluster, three Zones specifically, Jimma, Ilu Aba Bora and South West Shewa Zones were selected using simple random sampling technique. Out of 90 secondary schools (Jimma 35, Ilu Aba Bora 31, South west Shewa, 24), 32 (Thirty two) schools were included in the study through proportionate, simple random sampling methods. The technique was believed to give equal chance to secondary schools of the zone to be included in the study and enhanced the representativeness of the secondary schools in the cluster. The participants for this study were 973 teachers who teach in these 32 secondary schools. In addition, the 2014/2015 Grade 10 national examination score of 14882 students in the schools were used in this study.

\section{Instrument}

School Climate Index (SCI) questionnaire developed by TschannenMoran, Parish and Dipaola (2006) was used as data gathering tool in this study. These authors developed the school Climate Index (SCI) as a consolidated framework by combining the elements of Organizational Climate Descriptive Questionnaire (OCDQ) used to measure the openness of schools (developed by Hoy \& Sabo, 1998; Hoy, Tarter \& Kottkamp, 1991) and elements of Organizational Health Inventory (OHI) used to measure the health of schools (developed by Hoy and Feldman, 1987). The developers of the SCI employed second-order factor analysis to combine the subscales of the $\mathrm{OHI}$ and the OCDQ and found that from the 12 dimensions of the two frameworks there were four strong dimensions that emerged: collegial leadership, teacher professionalism, academic press, and community engagement.

Accordingly, the SCI was used as the primary instrument to gather information on the perceptions of the teachers in the sample of secondary schools and contains 28 Likert-type items with a 5-point scale in which the response choices include never, rarely, sometimes, often, very frequently. For this study, sample reliability of the instrument was evaluated using the Cronbach alpha coefficient of internal consistency. To this end, a pilot study of the questionnaire was conducted using purposive sampling of one secondary school which is similar to the ones included in the study. The Cronbach alpha reliability coefficient for the total instrument was 0.933 indicating the instrument was reliable. Since analysis of data for this study 
involved categorizing the instrument items into subscales, reliability coefficients were also found for the subscales. These reliability coefficients ranged with collegial leadership at 0.838 , teacher professionalism at 0.841 , academic press at 0.767, and community engagement at 0.782. Gay, Mills and Airasian (2006) highlighted that the minimum acceptable level of reliability differs among test types, but in general, the closer the reliability coefficient is to 1.0 , the more reliable the test is. The teachers in the pilot study were chosen because they had a similar background and knowledge to the target population about the issues being investigated. They did not form part of the group to be surveyed.

\section{Procedure}

Thirty two secondary schools were contacted by the researcher to get their consent for participating in the study. The school principals, department heads and teachers from these participating schools became the subjects. The SCI survey questionnaire was administered to the participants by the researcher and assistant data collectors during the regularly work time. The Zone Education Bureau examination unit that is directly responsible for the management of the national and regional examinations data was contacted to obtain the results of the 2014/2015 GSELCE examinations for the participating schools. The items in the survey questionnaire measure the teachers' perceptions of their school's climate, the independent variable in the study. The 2014/2015 SELCE scores were used as the dependent variable.

\section{Data Analysis}

In this study, the focus is on the collective teachers' perception at school level. Hoy and Sabo (1998) argued that the unit of analysis in school climate studies should be the school and not individuals because the variables being studied reflect organizational properties. In light of this, the school was considered the unit of analysis. Organizational climate is a description of the school and not of the individuals in the school. Likewise, academic achievement was calculated at the school level and not at the individual student level.

Descriptive statistics such as mean and standard deviation were first calculated for collegial leadership, teacher professionalism, academic press, community engagement, and student test scores to ensure that there was variability in the data collected. Pearson $r$ correlation coefficient was then computed using the two sets of data gathered from the schools: the school/organizational climate element scores and student achievement on $10^{\text {th }}$ grade examination scores. Multiple regression analysis was then conducted to find out the independent effects of each subscale of school 
climate on student achievement. These analyses assisted the researcher in examining the intercorrelations of the four dimensions of school climate being utilized in this study, as well as the relationship of each to student examination achievement.

Multiple regression technique gave a more detailed analysis as it enabled the examination of the influence of each climate dimension on student achievement, controlling for all other climate variables. It also allowed the researcher to determine the combined effect of the variables (Gay, Mills, \& Airasian, 2006). Certain assumptions must be tested and met in order for the results of multiple regression analysis to be useful. It assumes that variables have normal distributions and that the relation between the dependent and the independent variable is linear when all other independent variables are held constant. Observations of the visual representations of the histogram, scattered plot, and partial plots revealed that the assumptions of normality and linearity were met. A common problem that arises in multiple regression analysis is that of multi-collinearity. This basically means that two or more of the independent variables being used are highly correlated with each other and in effect measure the same thing. This makes it difficult to identify the unique relation between each predictor variable and the dependent variable (Urdan, 2005). The collinearity statistics for this study revealed that none of the Variance Inflation Factors were above 10. In research this is said to be an acceptable number to test for multi-collinearity as any number above 10 would be cause for concern.

\section{Ethical considerations}

Approval was granted from Zonal education offices before contacting the schools. Permission was sought from principals before any contact was made with the teachers. Consent was secured from each teacher before they filled out the surveys questionnaire and the researcher also explained how anonymity would be maintained throughout the study. Respondents were reminded not to write their name on the questionnaire and informed of the purpose, methods and time frame of the study. Likewise the results were reported collectively so there was anonymity for participants involved.

\section{Limitations}

The study involved the perceptions of teachers only. The supportive staff, parents and students were not included in the study. The responses of these groups might have provided a valuable counterpoint to the responses of the teachers. The climate of school organizations can be examined from different perspectives using several different tools. This study focused fully on the use of the school climate index; thus, its findings are limited to the factors measured by this scales. All other possible definitions of school 
climate were excluded when this instrument was selected. Many aspects of school climate, such as the social component, are not encompassed by this instrument and thus not addressed in this study. Achievement is a concept that can be measured in various ways. For the purposes of this study, achievement was measured exclusively by mean scores from a standardized exam. The latter might not fully reflect the achievement of a school as achievement could be based on growth, percent of students who are successful and the like.

\section{Results of the study}

A quantitative research design was employed to find out if there were relationships between organizational school climate and student achievement in secondary schools of west Oromia in Ethiopia. Thirty-two schools were involved in this study, and data were collected from these schools concerning the teachers' perception on their schools' climates. In addition, the 2014/2015 tenth grade national examination scores of students in the sample schools were used as dependent variable in this study. The results of the study were discussed as follows.

\section{Participants in Study}

According to Hoy and Sabo, (1998), the nature of school climate is best studied at the school level rather than at the individual level because school climate variables reflect collective organizational behaviours. The study followed this assumption in aggregating participants' responses to form school means that were then used in the analyses. The participating schools and the sample of participating teachers are presented in the Table 1 below:

Table 1: Schools, Teachers and Students Participating in the Study

\begin{tabular}{|c|c|c|c|c|c|c|c|}
\hline \multirow{2}{*}{\multicolumn{2}{|c|}{ Items }} & \multirow{2}{*}{ Category } & \multicolumn{2}{|c|}{ Schools } & \multicolumn{2}{|c|}{ Teacher } & Students \\
\hline & & & Count & $\%$ & Count & $\%$ & Count \\
\hline \multirow{4}{*}{ Zone } & & Ilu Aba Bora & 12 & 37.5 & 445 & 45.7 & 5585 \\
\hline & & Jimma & 10 & 31.25 & 369 & 37.9 & 4894 \\
\hline & & South West Shewa & 10 & 31.25 & 159 & 16.3 & 4403 \\
\hline & & Total & 32 & 100 & 973 & 100 & 14882 \\
\hline
\end{tabular}

As indicted in the Table 1 above, a total of 32 schools, 973 teachers and 14882 students were involved in the study. Specifically, 445 (45.7\%) teachers from Ilu Aba Bora zone, 369 (37.9\%) Jimma and 159 (16.3\%) from South west shewa were included in the study proportional to the teachers population in the respective Zones. 


\section{Descriptive statistics for the variables in the study}

Table 2 examined the mean scores of the major variables involved in the study vis $a$ vis the sample schools. The variables that measured the school climate index were rated on five point-scales (one to five) with one being the lowest score and five being the highest. Then the mean scores were compared with 3 (which is "sometimes") to indicate the level of SCI as perceived by the teachers. If the mean score on the SCI was higher than the mean (which is 3 or "sometimes"), the researcher assumed that the school climate was positive and vice versa. The mean scores for ESELCE on the schools were obtained by averaging 10 subjects the students took on the grade 10 national examination. The mean was first computed for an individual student on all subjects then calculated for each school and across all schools. According to the Ethiopia education and training policy, the score of 50 percent and above is considered as a pass mark in an examination. Accordingly, in this study 2 (50\%) out of 4 (100\%) ESELCE score is considered as a pass mark (mean or average score). The mean for each of the four factors of school climate was calculated by averaging the scores for all of the questions within each factor for the 973 teachers in the participating schools. Hence, the mean for the overall SCI represents an average of all the responses for all of the 28 survey items. The reports of the descriptive statistics were presented in Table 2 below.

Table 2: Descriptive statistics for the variables in the study

\begin{tabular}{|c|c|c|c|c|c|c|c|}
\hline No & $\begin{array}{l}\text { School } \\
\text { Name }\end{array}$ & $\begin{array}{c}\text { Collegial } \\
\text { Leadership }\end{array}$ & $\begin{array}{c}\text { Teacher } \\
\text { Professionalism }\end{array}$ & $\begin{array}{l}\text { Academic } \\
\text { Press }\end{array}$ & $\begin{array}{l}\text { Community } \\
\text { Engagement }\end{array}$ & SCI & $\begin{array}{l}\text { ESELC } \\
\text { E score }\end{array}$ \\
\hline & Dembi & 4.05 & 4.32 & 4.09 & 3.50 & 4.11 & 1.72 \\
\hline & Gechi & 3.71 & 4.15 & 3.63 & 2.72 & 3.66 & 1.73 \\
\hline & Gore & 2.95 & 3.22 & 2.99 & 2.67 & 3.16 & 1.44 \\
\hline & Uka & 2.70 & 3.05 & 2.97 & 2.68 & 2.98 & 1.45 \\
\hline & Beddle & 3.56 & 3.67 & 3.37 & 3.07 & 3.64 & 1.46 \\
\hline & Yebu & 3.63 & 3.77 & 3.73 & 3.20 & 3.71 & 2.21 \\
\hline & Agaro & 3.47 & 3.80 & 3.27 & 2.87 & 3.56 & 2.31 \\
\hline & $\begin{array}{c}\mathrm{L} / \text { Genn } \\
\text { et }\end{array}$ & 4.20 & 4.13 & 4.15 & 3.65 & 4.15 & 1.88 \\
\hline & Sekka & 3.49 & 3.83 & 3.56 & 2.82 & 3.56 & 1.92 \\
\hline & Serbo & 3.95 & 3.99 & 3.95 & 3.23 & 3.93 & 2.33 \\
\hline & Bulbul & 3.40 & 3.38 & 3.29 & 2.84 & 3.33 & 1.86 \\
\hline & Tobba & 4.40 & 4.64 & 4.23 & 3.76 & 4.43 & 2.13 \\
\hline & H/Fire & 4.33 & 4.33 & 4.20 & 3.53 & 4.22 & 1.64 \\
\hline & Chittu & 2.32 & 2.39 & 2.37 & 1.86 & 2.45 & 1.83 \\
\hline & Dillalea & 1.76 & 1.68 & 1.73 & 1.44 & 1.57 & 1.84 \\
\hline & Teji & 1.96 & 1.92 & 1.88 & 1.52 & 1.83 & 1.65 \\
\hline & Goro & 2.56 & 2.62 & 2.74 & 2.12 & 2.49 & 1.92 \\
\hline & Delidak & 3.29 & 3.25 & 3.05 & 2.51 & 3.10 & \\
\hline & Gindo & 3.26 & 2.95 & 2.94 & 1.85 & 2.83 & 1.68 \\
\hline & $\begin{array}{l}\text { Derge } \\
\text { Kota }\end{array}$ & 3.97 & 4.25 & 3.87 & 2.88 & 3.86 & 2.21 \\
\hline & Bantu & 3.03 & 3.09 & 2.67 & 2.78 & 3.02 & 1.47 \\
\hline
\end{tabular}




\begin{tabular}{|c|c|c|c|c|c|c|c|}
\hline & Dariyan & 3.07 & 3.30 & 3.03 & 2.78 & 3.13 & 1.69 \\
\hline & Alge & 2.75 & 2.57 & 2.98 & 2.05 & 2.63 & 1.55 \\
\hline & Bure & 3.04 & 3.13 & 2.89 & 2.39 & 3.00 & 1.68 \\
\hline & Chora & 2.69 & 2.92 & 2.73 & 2.38 & 2.82 & 1.52 \\
\hline & Darmu & 2.84 & 2.96 & 2.86 & 2.51 & 2.94 & 1.59 \\
\hline & Hurumu & 3.13 & 3.26 & 3.22 & 2.78 & 3.22 & 1.46 \\
\hline & Mettu & 3.00 & 3.15 & 2.95 & 2.43 & 3.01 & 1.45 \\
\hline $\begin{array}{c}\text { Abdi } \\
\text { Bori }\end{array}$ & 2.92 & 3.08 & 3.16 & 2.29 & 3.01 & 1.82 \\
\hline & $\begin{array}{c}\text { Asanda } \\
\text { bo }\end{array}$ & 3.00 & 3.61 & 3.21 & 2.28 & 3.12 & 1.81 \\
\hline & Dedo & 3.58 & 3.84 & 3.51 & 2.62 & 3.49 & 2.34 \\
\hline & Sokoru & 3.01 & 3.19 & 3.03 & 2.32 & 2.93 & 2.11 \\
\hline & Total & 3.24 & 3.42 & 3.23 & 2.67 & 3.29 & 1.79 \\
\hline
\end{tabular}

As seen in Table 2, the mean score for the School Climate Index showed that 24 schools (75\%) had scored above the mean and 8 schools (25\%) had averages below the mean value. Regarding the ESELCE examination results, 7 schools $(22.58 \%)$ had averages above the mean and 24 schools (77.42\%) had scores below the mean.

Table 3: Descriptive Statistics for the School climate Factors and ESELCE scores

\begin{tabular}{cccccc}
\hline & $\mathrm{N}$ & $\begin{array}{c}\text { Descriptive Statistics } \\
\text { Minimum }\end{array}$ & Maximum & Mean & $\begin{array}{c}\text { Std. } \\
\text { Deviation }\end{array}$ \\
$\begin{array}{ccccc}\text { Collegial Leadership } \\
\text { Teacher }\end{array}$ & 912 & 1.00 & 5.00 & 3.24 & 0.86 \\
$\begin{array}{c}\text { Professionalism } \\
\text { Academic Press }\end{array}$ & 981 & 1.00 & 5.00 & 3.42 & 0.83 \\
$\quad$ Community & 914 & 1.00 & 5.00 & 3.23 & 0.81 \\
Engagement & & 1.00 & 5.00 & 2.67 & 0.70 \\
$\quad$ SCI & 772 & 1.00 & 5.00 & 3.29 & 0.72 \\
ESELCE Score & 14877 & .00 & 4.00 & 1.79 & 0.66 \\
\hline
\end{tabular}

When we evaluate the mean for each of the four variables of school climate (Table 3), teacher professionalism was found be high $(\mathrm{M}=3.42$, $\mathrm{SD}=0.83)$ followed by collegial leadership $(\mathrm{M}=3.24, \mathrm{SD}=0.86)$ and academic press $(\mathrm{M}=3.23, \mathrm{SD}=0.81)$. The score for community engagement factor was rated below the average $(\mathrm{M}=2.67 \mathrm{SD}=0.70)$, signifying that this practice was evaluated by the respondents as weak or negative. The average ESELCE examination scores for all schools was far below the mean $(M=1.79$, $\mathrm{SD}=0.66)$.

One of the basic questions of this study aims at investigating whether a significant relationship exists between school climate and student achievement. Accordingly, correlation analysis was computed between the mean of each of the factors of school climate and the mean of the ESELCE scores for the schools participating in the study. The results were presented in the Table 4 below. 
Table 4: Correlation Results for the Variables in the Study

\begin{tabular}{llllll}
\hline & CL & TP & AP & CE & $\begin{array}{l}\text { ESELCE } \\
\text { Score }\end{array}$ \\
SCI & $.977^{* *}$ & $.981^{* *}$ & $.975^{* *}$ & $.948^{* *}$ & $.354^{*}$ \\
CL & & $.964^{* *}$ & $.969^{* *}$ & $.900^{* *}$ & $.379^{*}$ \\
TP & & & $.961^{* *}$ & $.896^{* *}$ & $.387^{*}$ \\
AP & & & $.900^{* *}$ & $.382^{*}$ \\
CE & & & & & .225 \\
\hline
\end{tabular}

$C L$ = Collegial Leadership; TP = Teacher Professionalism; AP = Academic Press; $\mathrm{CE}=$ Community Engagement. $N=32$

** Correlation is significant at the 0.01 level (2-tailed)

* Correlation is significant at the 0.05 level (2-tailed)

The results indicate that there is a significant and positive correlation between overall school climate and student achievement $\left(r=.354 \quad r^{2}=\right.$ $0.125, \mathrm{P}<0.05$ ). It is important to note that although there is a significant relationship between the two variables, the correlation coefficient is weak. The $r 2$ value indicates that the school climate index explains $12.5 \%$ of the variance in student achievement scores in ESELCE.

Further examination at the correlation analysis presented in the above Table shows important results regarding factors of school climate vis $a$ vis student scores. The data in the Table 4 depicted that the collegial leadership sub scale $\left(r=0.379, r^{2}=0.144, P<0.05\right)$, teacher professionalism $(r=0.387$, $\left.\mathrm{r}^{2}=0.150, \mathrm{P}<0.05\right)$ and academic press $\left(\mathrm{r}=0.382, \mathrm{r}^{2}=.146, \mathrm{P}<0.05\right)$ were significantly and moderately correlated to students achievement. On the other hand, the community engagement $\left(r=0.225 r^{2}=0.051, P>0.05\right)$ sub scale showed no significant relationship with students performance on ESELCE.

The third objective of this study is examining the relative weight of each of the sub scales of the school climate as predictors of student achievement on Ethiopia secondary education leaving certificate examination. Multiple linear regression analysis was used to determine the independent effects of each of the school climate variables on student achievement. The results are shown in Table 5 below.

Table 5: Multiple Regression Analysis for School Climate Variables

\begin{tabular}{cccc}
\hline & Unstandardized & $\mathrm{B}$ & $\begin{array}{c}\text { Standardized } \\
\text { Constant }\end{array}$ \\
Collegial Leadership & & 1.23 & $\beta$ \\
Teacher Professionalism & & .310 & $.705^{*}$ \\
Academic Press & & .526 & $1.30^{*}$ \\
Community Engagement & & .327 & $.710^{*}$ \\
$\mathrm{R}^{2}$ & .28 & -.058 & -.117 \\
$\Delta \mathrm{R}^{2}$ & .14 & & \\
$\mathrm{~F}$ & $9.96 *$ & & \\
& & & \\
\hline
\end{tabular}


Using the enter method it was found that the four climate variables had an overall positive effect on explaining the variance in students achievement $F\left((5,32)=9.96, p<0.05, R^{2}=0.28, \Delta R^{2}=0.14\right)$. The result shows that $28 \%$ of the variation in student achievement at ESELCE can be explained by the four sub scales of the school climate indexes combined. When adjusted $\mathrm{R}^{2}$ is used the model predicts about $14 \%$ of variation in student achievement scores at ESELCE (this statistic adjusts for sample size and number of independent variables in the model, Urdan, 2005).

A close look at the sub scales of school climate (Table 5) shows that collegial leadership ( $\mathrm{B}=.310, \beta=.705, \mathrm{P}<0.05$ ), teacher professionalism $(\mathrm{B}=.526, \beta=.1 .30, \mathrm{P}<0.05)$ and academic press $(\mathrm{B}=.327, \beta=.710, \mathrm{P}<$ $0.05)$ had significant independent effects on student achievement as measured by ESELCE scores. However, community engagement $(\mathrm{B}=-.058$, $\beta=-.117$, ns) did not significantly predict the variance in student achievement at ESELCE.

\section{Discussions}

Student performance on national examination has become increasingly important in Ethiopia education system. The examination results have become the means of documenting the performance of schools. Educators and educational leaders are examining ways to increase student performance on national examinations. One area that has been linked with student achievement is school climate (Goddard, Sweetland \& Hoy, 2000; Heck, 2000; Hoy \& Hannum, 1997; Johnson \& Stevens, 2006; Smith, 2002; Tschannen-Moran, Parish \& Dipaola, 2006; Uline \& Tschannen-Moran, 2008; Bulach, Malone, \& Castleman, 1995; B. Johnson, 1998; P. Johnson, 1998; Linzy, 2000; Wallet, 1990; Walton, 1990). This study examined the relationship between overall school climate and student achievement as measured by the ESELCE scores. The relative effect of the subscale measures of school climate (collegial leadership, teacher professionalism, academic press and community engagement) as they related to student achievement was also studied. Although climate had been defined in a variety of ways throughout the research, for the purposes of this study, based on the review of the literature and the theoretical framework developed by Tschannen-Moran, Parish \& Dipaola, (2006) organisational/school climate is described by factors including collegial leadership, teachers' professionalism, academic press and community engagement. The relationship between school climate and student achievement was examined through the use of two statistical methodologies: correlation and a multiple regression. 
One of the findings of this study is that school climate has a significant and positive relationship with student achievement in Ethiopia secondary schools. This finding is similar to the results of the previous studies conducted in different countries which revealed relationships between school climate and student achievement (Hoy \& Hannum, 1997; Smith, 2002; Tschannen-Moran, Parish \& Dipaola, 2006). Here, it is important to note that the relationship found in this study is a weak positive relationship, but nonetheless, a significant one.

The second major finding was with regard to the relationship between the subscales of school climate and student achievement. The study shows that three of the subscales of school climate i.e. the collegial leadership, teacher professionalism and academic press were significantly and moderately correlated with student achievement while the community engagement sub scale was not. Other studies conducted by Dian Vasquez (2011) and Tschannen-Moran, Parish \& Dipaola (2006) using similar instrument revealed that teacher professionalism, academic press, and community engagement were significantly correlated with student achievement. In these two studies, community engagement had the highest correlation and academic press closely followed. This study did not reveal significant relationship between community engagement and student achievement in the correlation analysis.

The multiple regression analysis revealed a third major finding of this study. The four factors used both for the SCI as predictor variables in the regression model were shown to have a significant relationship with student achievement when viewed as a whole, but they generated more varied results when examined individually. Teachers' professionalism is the most positive predictor of student achievement in Ethiopia secondary schools. This factor of school climate depicted a significant positive correlation with academic achievement as well as emerged as the most significant predictor of academic achievement in the multiple regression analysis. Similarly collegial leadership and academic press are also found to be significant predictor of academic achievement. Previous studies conducted in the area supports this finding in that academic press is a significant predictor of academic achievement (Goddard, Sweetland, \& Hoy, 2000; Hoy \& Hannum, 1997; Hoy \& Sabo, 1998; Smith, 2002). This study found no independent effect of community engagement on student achievement. In contrast, the study done in Virginia found that only community engagement had independent effects on student achievement (Uline \& Tschannen-Moran 2008).

The three subscales of school climate that revealed significant correlations with academic achievement (collegial leadership, teacher professionalism and academic press) indicate that these factors are worth assessing if there is an interest in improving academic performance of 
students. It appears that schools that exercise collegial leadership, give due emphasis for teachers professionalism and acknowledge the academic achievements of students tend to be more successful than schools that do not. From this study it can be concluded that a type of leadership that is friendly and open are more effective for the Ethiopia school setting.

In this study, the best predictor of academic achievement in Ethiopia secondary schools was teacher's professionalism. If teachers work together, respect each other, and accomplish their job with enthusiasm, this could add to a healthier school environment which could then lead to improved student success. Sweetland and Hoy (2000) studied 86 New Jersey middle schools and found a significant correlation between teacher professionalism and teacher empowerment and the latter made significant independent contributions to student achievement. Since this study reveals that this subscale of school climate has such a significant effect on academic achievement in Ethiopia secondary schools, the teacher professionalism subscale serves as a crucial area for Ethiopia school administrators and policy-makers to consider when focusing on academic success of secondary school students. With regard to academic press sub scale it can be concluded that schools that set high standards for academic performance, set an orderly and serious learning environment, and maintain definite standards of performance tend to do better academically than schools that do not.

In this study, the community engagement subscale does not have a significant relationship with student achievement. That is not to say, however, that this subscale is not important. As discussed above, there is an overall significant relationship between school climate and student achievement. The effects of community engagement on student achievement in Ethiopia schools may not be direct but may work through other mediating factors. If schools foster positive relations with the community such as involving them in planning of school activities and in regular discussion of school issues, there could be a positive effect on student achievement. No further conclusions on the effect of this subscale on student academic achievement in Ethiopia schools can be drawn without further research.

\section{Conclusion}

It was important to study the impact of school climate on student achievement as well as to identify the factors that make up a school's climate to enable school leaders to understand the climate of their schools and to consciously plan and implement strategies designed to improve their schools' climates. It was also timely and relevant to study school climate and its effect on student achievement because of the increasingly high stakes for underachievement. 
As student performance continues to have implications for both students, parents and schools, educators and educational leaders continue to look for ways to improve those scores. The fact that there was a relationship between school climate and student achievement is a reason to continue to examine school climate in greater depth in many countries. Consistent with many other research findings, this study showed that there is a significant positive relationship between school climate and student achievement. Besides, the three subscales (teacher professionalism, collegial leadership and academic press) remain significant facets of the school climate framework as they do have a positive correlation with school climate, which in turn has a significant relationship with achievement. These results suggest that an emphasis on school climate and its variables may be a good place for schools to start when trying to improve students' academic achievement. While other climate factors are important and a direct effect on student success, this study revealed that increasing teacher professionalism could have the greatest impact. Although this study like other studies done in different countries showed a significant positive relationship between academic achievement and school climate, it also discovered some unique findings that community engagement has no independent effect on students' academic achievement; and this might be a direct effect of the setting of the study.

\section{Recommendations}

Based on the findings of this study, the following recommendations are presented:

This study has major practical implications for educational officers working at different levels in light of the recently introduced Ethiopia school improvement programs initiative. This program is expected to improve student academic achievements focusing on four domains: teaching-learning, school leadership, and school climate and community participation. This study is timely in that it revealed findings that can definitely speak to this reform initiative. School leaders and education administrators, in their efforts to meet the challenges of the general secondary education reform initiative, can reflect on how school climate can be improved in their schools.

The successful function of a school depends upon the presence of a strong and positive climate (Deal \& Peterson, 1999; Freiberg \& Stein, 1999). This study revealed a significant relationship between positive school climate and student achievement. Thus, school principals and administrators need to be cognizant of the effects of school climate on student achievement as well as the effect of the different components of school climate on achievement as they continue to seek ways of improving their schools. School leaders should design school improvement plans that entail the school 
climate construct. This study reveals that school climate has a significant relationship with student achievement, so including it in the school improvement program could lead to improved academic achievement. School leaders need to find ways of including the community in the life of the school and foster positive relationships with the community. It is important that schools involve the community in the planning of different school activities. Improved school-community relations can also have a positive effect on school climate which in turn has a positive effect on achievement. Educators should be cognizant of the climate that exists in a school because it does affect academic achievement. Principals in particular need to be mindful that the climate of a school affect achievement and the former can be enhanced to improve results.

It is argued that schools that exercise collegial leadership, give due emphasis for teachers professionalism and acknowledge the academic achievements of students tend to be more successful than schools that do not. Thus, it suggested that school principals should involve teachers in decision making, exercise leadership that is friendly and open and being supportive while not being directive or restrictive. In order to enhance academic engagement of students, it is important that school leaders and teachers should set high standards for academic performance, set an orderly and serious learning environment and maintain definite standards of performance.

\section{Suggestions for Future Research}

The perceptions of supportive staff, students and parents were not included in this study; a study that involves the perceptions of these groups would be considered as it contributes to understanding of school's climate. In this study, the community engagement subscale does not have a significant relationship with student achievement which is contrary to findings in developed countries. Further studies using this particular instrument are needed.

\section{References:}

1. Anderson, Carolyn S. (1982). The Search for school climate: A Review of the Research. Review of Educational Research, 52(3), 368-420.

2. Astor, R.A, Guerra, N., \& Van Acker, R. (2010). How can we improve school safety research? Educational Researcher, 39 (1), 69-78.

3. Barnard, W.M. (2004). Parent involvement in elementary school and educational attainment. Children and Youth Services Review, 26, 3962. 
4. Barton, P. E. (2004). Why does the gap persist? Educational Leadership, 62 (3), 8-13.

5. Blase, J., \& Blase, J. (2000). Effective instructional leadership: Teachers' perspectives on how principals promote teaching and learning in schools. Journal of Educational Administration, 38(2), 130 .

6. Bogdan, R.C and Biklen, S.K.(2007).Qualitative Research For Education: An Introduction to Theories and Methods. Boston: Pearson Education Inc.

7. Bulach, C.R., Malone, B., \& Castleman, C. (19950). An investigation of variables related to student achievement. Mid-western Educational Researcher, 8(2), 23-29.

8. Cawelti, G. (2000). Portrait of a benchmark school. Educational Leadership, 57 (5), 42-44.

9. Deal, T.E. \& Peterson, K.D. (1999). Shaping school culture: The heart of school leadership. San Francisco: Jossey-Bass.

10. Eccles, J.S., Wigfield, A., Midgley, C., Reuman, D., MacIver, D., \& Feldlaufer, H. (1993). Negative effects of traditional middle schools on students' motivation. Elementary School Journal, 93, 553-574.

11. Evans, M. A., Shaw, D., \& Bell, M. (2000). Home literacy activities and their influence on early literacy skills. Canadian Journal of Experimental Psychology, 54, 1196-1221.

12. Fan, X. \& Chen, M. (2001). Parental involvement and students' academic achievement: A meta-analysis. Educational Psychology Review 13 (1), 1-22.

13. Finnan, C., Schnepel, K., \& Anderson, L. (2003). Powerful learning environments: the critical link between school and classroom cultures. Journal of Education for Students Placed At Risk, 8(4), pp.391-418.

14. Freiberg, J. H., \& Stein, T. A. (2003). Measuring, improving, and sustaining healthy learning environments. In J. H. Freiberg (Ed.), School climate (pp. 11). Routledge Falmer, London: Falmer Press.

15. Gay, L. R., Mills, G. E., \& Airasian (2006). Educational research: Competencies for analysis and applications (8th Ed.). Upper Saddle River, NJ: Pearson Education, Inc.

16. Ghaith, G. (2003). The relationship between forms of instruction, achievement and perceptions of classroom climate. Educational Research, 45, 83-93.

17. Goddard, R. D., Hoy, W. K., \& Woolfolk, A. (2000). Collective teacher efficacy: Its meaning, measure, and effect on student achievement. American Educational Research Journal, 37, 479-507. 
18. Goleman, D. (2006). The socially intelligent leader. Educational Leadership, 64(1), 76-80.

19. Gottfredson, G., Gottfredson, D, Payne, A., \& Gottfredson, N. (2005). School Climate Predictors of School Disorder: Results from a National Study of Delinquency Prevention in Schools. Journal of Research in Crime and Delinquency, 42(4) 412-444

20. Gregory, A., Cornell, D., Fan, X., Sheras, P., Shih, T., \& Huang, F. (2010). Authoritative school discipline: High school practices associated with lower student bullying and victimization. Journal of Educational Psychology, 102, 483-496.

21. Hallinger, P. (2003). Leading educational change: Reflections on the practice of instructional and transformational leadership. Cambridge Journal of Education, 33(3), 329-352.

22. Halpin, A. W., \& Croft, D. B. (1963). The organizational climate of schools. Chicago: Midwest Administration Center.

23. Heck, R. H. (2000). Examining the impact of school quality on school outcomes and improvement: A value-added approach. Education Administration Quarterly, 36 (4), 513-552.

24. Hoy, A. W., \& Hoy, W. K. (2009). Instructional Leadership: A research-based guide to learning in schools. (3rd ed.). Pearson Inc.

25. Hoy, W. K., \& Clover, S. (1986). Elementary school climate: A revision of the OCDQ. Educational Administration Quarterly, 22, 93-110.

26. Hoy, W. K., \& Miskel, C. G. (1991). Educational administration: Theory into practice. New York: McGraw-Hill.

27. Hoy, W. K., \& Miskel, C. G. (1996). Educational administration: Theory, research, and practice (5th ed.). New York: McGraw-Hill.

28. Hoy, W. K., \& Sabo, D. J. (1998). Quality middle schools: Open and healthy. Thousand Oaks, CA: Corwin Press.

29. Hoy, W., \& Feldman, J. (1987). Organizational Health: The concept and its measure: Journal of Research \& Development in Education, 20(4), 30-37.

30. Hoy, W., \& Hannum, J.W. (1997). Middle School climate: An empirical assessment of organizational health and student achievement. Educational Administration Quarterly, 33 (3)

31. Hoy, W., Hannum, J., \& Tschannen-Moran, M. (1998). Organizational climate and student achievement: A parsimonious view and longitudinal view. Journal of School Leadership, 8, 336359.

32. Hoy, W.K., \& Tarter, C.J. (1997). The road to open and healthy schools: A handbook for change (middle and secondary school ed.). Thousand Oaks, CA: Corwin Press, Inc. 
33. Hoy, W.K., Smith, P. A., \& Sweetland, S. R. (2002). The development of the organizational climate index for high schools: Its measure and relationship to faculty trust. The High School Journal, 86 (2), 38- 49. Organizational Climate and Student Achievement

34. Johnson, B. (1998). The relationship between elementary school teachers' perceptions of school climate, student achievement, teacher characteristics, and community and school context (Doctoral dissertation, University of New Mexico, 1998).

35. Johnson, B., \& Stevens, J. J. (2006). Student achievement and elementary teachers' perceptions of school climate. Learning Environments Research, 9 (2), 111-122.

36. Klinger, D. A. (2000). Hierarchical linear modelling of students and school effects on academic achievement: New Brunswick school climate study. Canadian Journal of Education, 25 (2), 41.

37. Lee, T., Cornell, D., Gregory, A., Fan, X (2011). High suspension schools and dropout rates for black and white students. Education and Treatment of Children, 34(2), 167-192.

38. Linzy, M.J.S. (1990). A comprehensive study of the relationship between school climates and student achievement in fifth, seventh, and ninth grades in a north Florida school district (Doctoral dissertation, Florida State University, 1990).

39. McMillan, J. H. (2004). Educational research: Fundamentals for the consumer. Boston, MA: Pearson Education, Inc.

40. Miller, R. G., \& Calfee, R. C. (2004). Making thinking visible. Science and Children, 42(3), 20-25.

41. National School Climate Council (2007). The School Climate Challenge: Narrowing the gap between school climate research and school climate policy, practice guidelines and teacher education policy. http://www.schoolclimate.org/climate/advocacy.php Retrieved in February, 2015.

42. OEB (2013). Educational statistics Annual Abstract. Addis Aaba : SIVANET Printing

43. OECD (2009). Creating effective teaching and learning environment: First results of Teaching and Learning International Survey (TALIS). OECD.

44. Okpala, C. O., Okpala, A. O., \& Smith, F. E. (2001). Parental involvement, instructional expenditures, family socioeconomic attributes, and student achievement. The Journal of Educational Research, 95(2), 110-115.

45. Opdenakker, M., \& Damme, J. (2001). Relationship between school composition and characteristics of school process and their effects on 
math achievement. British Educational Research Journal, 47(4), 407432.

46. Oppdenaker \& Damme, 2001

47. Owens, Robert G. (1987). Organizational Behaviour in Education, $3^{\text {rd }}$. ed. Englewood Cliffs, New Jersy: Prentice- Hall, Inc.

48. P. Johnson, 1998

49. Perkins, B.K. (2006). Where we learn: The CUBE survey of urban school climate. Retrieved in February, 2015 from http://www.nsba.org/SecondaryMenu/CUBE/Publications

50. Plucker, J. A. (1998). The relationship between school climate conditions and student aspirations. The Journal of Educational Research, 91(4), 240-246.

51. Rumberger, R., \& Thomas, S. (2000). The distribution of dropout and turnover rates among suburban high schools. Sociology of Education, 73(1), 39-67.

52. Smith, P.A. (2002). The organizational health of high schools and student proficiency in mathematics. The International Journal of Educational Management, 16(2), 98-104.

53. Strayhorn, T. L. (2010). The role of schools, families, and psychological variables on Math achievement of black high school students. The High School Journal, 93(4), 177-194.

54. Tschannen-Moran, M., Parish, J., Dipaola, M. (2006). School climate: The interplay between interpersonal relationships and student achievement. Journal of School Leadership, 16(4), 386-415.

55. Uline, C., \& Tschannen-Moran, M. (2008). The walls speak: The interplay of quality factors, school climate and student achievement. Journal of Educational Administration, 46(1),55.

56. Urdan, T. C. (2005). Statistics in Plain English (2nd ed.) Mahwah, NJ: Lawrence Erlbaum Associates, Inc.

57. Van Houte, M. (2005). Climate or culture? A plea for conceptual clarity in school effectiveness research. School Effectiveness and School Improvement, 16 (1), 71-89.

58. Walton, L.E. (1990). The relationship of teachers' perceptions of school climate and principal competencies with the third-grade Georgia criterion referenced test scores in rural Georgia elementary schools (Doctoral Dissertation, Georgia State University, 1990). 